\title{
Logistics and Supply Chain Management Research in Morocco: A Systematic Literature Review
}

\author{
Othmane Idrissi Fakhr Dine ${ }^{1} \&$ Nawfal Bahha ${ }^{1}$ \\ ${ }^{1}$ Cadi Ayyad University, Marrakech, LAREGO, Morocco \\ Correspondence: Nawfal Bahha, Ecole Nationale de Commerce et de Gestion (ENCG), Cadi Ayyad University, \\ Marrakech, Morocco. E-mail: nawfal.bahha@gmail.com
}

Received: March 27, 2021

Accepted: April 28, 2021

Online Published: May 5, 2021

doi:10.5539/ijbm.v16n6p66

URL: https://doi.org/10.5539/ijbm.v16n6p66

\begin{abstract}
This article has two objectives, the first is to present an analysis of the results of a systematic review of literature on logistics and supply chain management (SCM) in Morocco from 2010 to 2018, and second, to present a diagnosis of this research in order to propose a line of research which is little or not explored yet in the Moroccan context. To reach these objectives, we rely on the systematic review approach of literature and 51 articles were selected for final analysis. The results show that some laboratories are more active in logistics and SCM in the Moroccan context than others. Also, most of the articles included present a theoretical background that is not totally explored. Furthermore, our results reveal a dominance of articles highlighting logistics performance. This study presents a number of research tracks which take into consideration the recent evolutions in the logistics sector in Morocco.
\end{abstract}

Keywords: systematic literature review, logistics, supply chain management, Morocco

\section{Introduction}

In Morocco, the logistics sector has experienced strong growth and evolution over the last decade. It represents a major challenge given its positive impacts on the economic, social and sustainable development of the country. Given its importance, especially in the daily business of firms, the public authorities have built a proactive strategy aimed at making this sector a regional hub in the African continent. To reach this aim, several steps have been taken, such as the completion of regional planning, the structuring of logistics zone projects at the level of several regions, the construction and reorganization of new ports, etc. The implemented efforts allowed some significant progress as shown by its relative Logistics Performance Index score of $48.1 \%$ in 2018 and its 21 st rank in the Emerging Markets Logistics Index, thus recording the fastest-growing business destination in 2017 with $(+5.8 \%)$ (Note 1$)$.

From the professional side and in order to promote and strengthen governance, in particular, of the logistics sector, many agencies and offices were created such as the Moroccan Agency for Logistics Development (AMDL)(Note 2) whose essential role is the coordination of actions at the national level to improve logistics competitiveness around specific projects such as logistics zones. Also, the creation of the Moroccan Observatory for Logistics Competitiveness (OMCL) which is mainly responsible for measuring the logistics system's performance, ensuring a strategic watch, proposing improvements of logistical competitiveness, and monitoring the implementation of the National Logistics Strategy. For the reinforcement of the competencies in this sector, the National Board for Coordination of Logistics Training (BNCFL) has been launched for the development of a national training plan in logistics trade. Finally, for a better management of the logistics sector and an increase in the level of logistics practices, the National Commission for Logistic Standardization (CNNL) was created in 2015.

From the scientific research side, several scientific events (national and international conferences), as well as scientific journals, have been dedicated to logistics and SCM. Regarding this growing interest from policymakers, professionals as well as researchers, we decided to conduct a systematic review on this field of research, to investigate more deeply the state of research on logistics and SCM in Morocco. The rationale behind conducting this research is to review and to examine what is known from the large body of research in the domains of logistics and SCM in the Moroccan context. This review "consists of a synthesis of the scientific literature in response to a specific question. It uses explicit methods of searching, selecting and analyzing data 


\section{"(Zaugg et al., 2014).}

In Morocco, since the implementation of the National Logistics Development Strategy several scientific articles have been published on the topic of logistics and SCM. This research has contributed significantly to understanding the specificity of the logistics sector and SCM in Morocco. Notwithstanding, there are no studies, to our knowledge, that have tried to effectively systematize and map the research on logistics and SCM in Morocco. In this regard, we aim through this systematic review, to first establish a first "state of the art" of scientific research in this field of knowledge in Morocco and second to offer a "concrete agenda" for future lines of research for future exploration and development in logistics and SCM in Morocco. This research would be of particular interest to policymakers and firms seeking to design logistics strategies and make policies. These objectives are of great importance for Morocco, which has been identified as "an international logistics hub in Africa and the Mediterranean" (Note 3).

In order to address the objectives defined previously, we focus on the following research questions: 1) what topics are covered by researchers in logistics and SCM in Morocco? 2) Which fields of research are explored and what methodologies are adopted? Addressing these questions will lead us to integrate the relevant findings of studies included in this systematic review in order to identify where the conclusions converge and diverge. This will help to advance our knowledge of logistics and SCM in the Moroccan context and to better channel future research. The rest of the article is organized as follows: First, we will describe in more detail the systematic review methodology used to locate and select the relevant literature (section 2). We will then present some general characteristics of the studies examined using statistics (section 3). We will then present the results of our systematic review and discuss them in relation to the themes, sectors, and laboratories (Section 4) involved in logistics research and SCM. We will conclude with the main findings, implications, and recommendations for researchers, managers, and policymakers.

\section{Method}

The Method section describes in detail how the study was conducted, including conceptual and operational definitions of the variables used in the study, Different types of studies will rely on different methodologies; however, a complete description of the methods used enables the reader to evaluate the appropriateness of your methods and the reliability and the validity of your results, It also permits experienced investigators to replicate the study, If your manuscript is an update of an ongoing or earlier study and the method has been published in detail elsewhere, you may refer the reader to that source and simply give a brief synopsis of the method in this section.

This research study uses the descriptive systematic review approach to identify and analyze scientific articles that deal with logistics and SCM in Morocco. The systematic review is a literature review following a rigorous, transparent and reproducible process that attempts to identify, select, evaluate, analyze and synthesize in a systematic and comprehensive way the results of research on a specific topic (Transfield et al. 2003) , (Moynihan, 2004). Systematic reviews are now widely regarded as the least biased and more rational way to synthesize research findings, as well as a powerful tool for providing the best available knowledge on a research topic Moynihan (2004) and Fox (2005). The stages of the systematic review of the literature are: i) formulate a clear research question, ii) establish inclusion and exclusion criteria, iii) find relevant studies, iv) select studies according to criteria of inclusion and exclusion, v) assessment of the quality of selected articles, vi) summarize and synthesize the results of selected articles, and vii) interpret the results of the systematic review Transfield et al.(2003), Moynihan (2004), Alderson et al, 2004), Hemsley-Brown and Sharp (2003). This systematic review aims to answer the following two research questions: 1) What are the topics covered by researchers in the context of logistics and SCM in Morocco? 2) Which fields of research are explored and which methodologies are adopted? To be included in the systematic review, an article should deal with logistics and SCM in Morocco. Published articles (peer-reviewed) have been considered. Books, master thesis, conference papers and book reviews have been excluded due to time and resource constraints.

We assume, however, that relevant ideas and important scientific contributions included in books, conference papers and memoirs are often published in peer-reviewed articles. In addition, this systematic review covered the period from 2010 to 2018. The choice of this horizon is mainly related to the publication of National Logistics Development Strategy in 2010 and therefore, we wanted to understand the dynamics of research in logistics and SCM in Morocco since the appearance of this strategy. We used a search strategy that involves conducting a systematic electronic search by mobilizing two strings of keywords in English and French. As a result, the articles in both languages were examined. The electronic research covered five multidisciplinary databases including EBSCO, Emerald, ScienceDirect, Cairn and IMIST. This last database contains most of the logistics 
management publications in the Moroccan context. All identified documents were processed using the EndNote software which identifies and eliminates duplicate studies.

In all, 289 articles were identified. They break down as follows: 219 articles from the electronic search and 70 articles from the manual search. A first sorting based on the reading of the titles and summaries of the documents led us to exclude 170 documents that did not meet at least one of the inclusion / exclusion criteria. Further reading of the full text of the remaining 119 documents resulted in the exclusion of 47 documents. Thus, 72 documents crossed the double sorting. Each of these documents was carefully evaluated for its methodological quality by the two researchers. This step led us to exclude 21 documents. Thus, 51 documents were definitively included in the systematic review. All selected documents were computer-controlled. For the purposes of our study, we have designed a Microsoft Excel database containing, for each article: its references, the type of research (qualitative, quantitative or conceptual), the sector covered, the topic of the article, the research laboratories, professional affiliation and determinants of logistics performance.

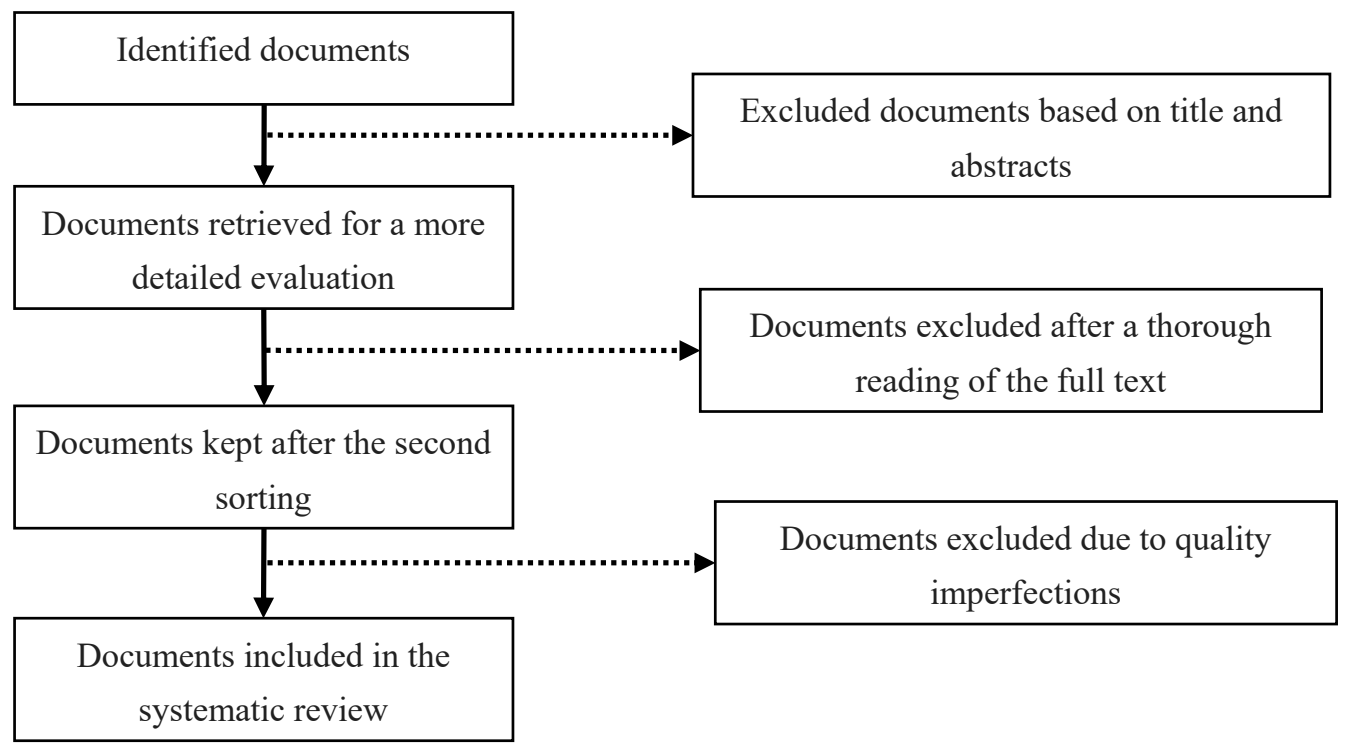

Figure 1. Flow diagram of the systematic review of the literature

\section{Descriptive Analysis of the Systematic Review}

In this section, we will present the results related to the number of publications and the Moroccan laboratories involved in logistics research and the SCM (section 3.1), the theoretical approaches and models implemented in the research field in Morocco on logistics and logistics, the SCM (section 3.2), and the themes analyzed by Moroccan researchers (section 3.3).

\subsection{Publication Trend in Logistics and SCM in Morocco}

The published articles trend is illustrated in Figure 2. It clearly shows that the number of works on logistics and SCM in Morocco has increased remarkably, especially since the year 2012 until the year 2016. About $69 \%$ of the selected articles are published in peer-reviewed national journals compared to $31 \%$ in peer-reviewed international journals. In addition, the French language remains the preferred publication language for Moroccan researchers with $70 \%$ of articles against $30 \%$ of articles only retained in English. Among all the articles selected, $41 \%$ used a quantitative methodology against $22 \%$ of qualitative articles. In addition, $10 \%$ of articles used mixed methods. Of the articles selected, $14 \%$ of articles are conceptual and $6 \%$ of them are literary journals. It should be noted that $(8 \%)$ of the selected articles do not present any method. 


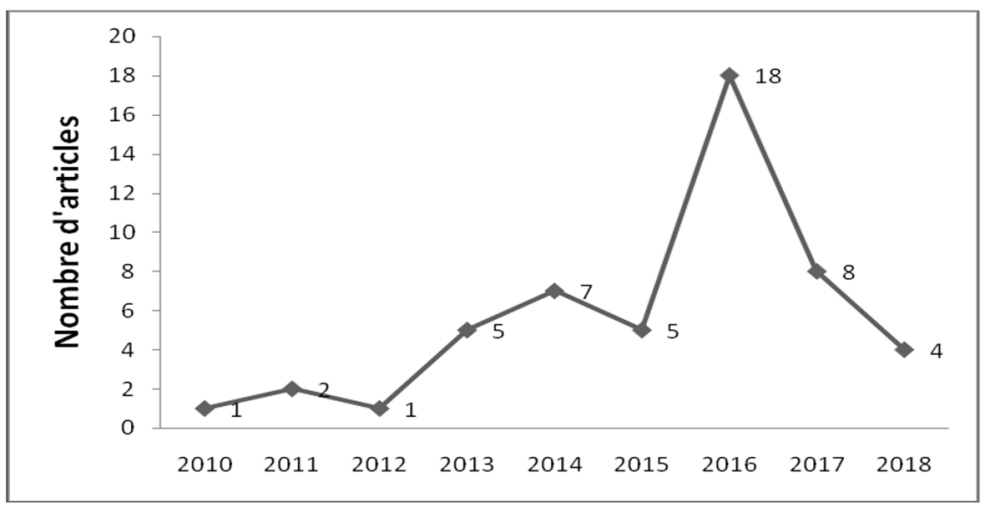

Figure 2. Publication trend from 2010 to 2018

Regarding the trend of publications by laboratory and industry (Table 1), the analysis of the articles selected in our systematic review of the literature clearly shows that some Moroccan research laboratories are well involved in research in logistics and SCM. In total, twenty-three laboratories and research teams are identified. Thus, at the national level, the Research Team in Transport Economics, Information Technology and Logistics (ERETTLOG) affiliated to Ibn Zohr University., Agadir is at the head of the laboratories that are very active in terms of publications on logistics with six publications. The Entrepreneurial Research, Audit and Marketing Research Group (GREFAM) of Abdelmalek Essaâdi University ranks second with four publications. LEMNA (Nantes) occupies the third position with three publications. Always in connection with the contribution of the laboratories to research in logistics and the SCM, the Laboratory of Research in Information Systems and Decision Support (LRSIAD) of Hassan I University, the Laboratory of Economy, Management and Sustainable Development (LEGDD) of Abdelmalek Essâadi University, the Organization Management Research Team (EREMOR) of the Faculty of Legal, Economic and Social Sciences (FSJES) of Mohammed V University in Rabat and the Center for Research in Management and Commerce (CRMC) of the University of Tetouan with two publications. Among the laboratories and research teams identified in our study, only one foreign laboratory is included; the Laboratory of Economics and Management of Nantes (LEMNA). Finally, fifteen laboratories each published a single article related to the theme of our systematic literature review.

Two observations are important to make at this level. The first is related to laboratories active in logistics research and SCM. The two laboratories located in Tangiers and Agadir insist on the importance of these two cities in the Moroccan logistics sector. The second is related to the research itself which is trying to find a cruising speed to meet the practical challenges of logistics and SCM practices. In this regard, El Baz et al. (2018) in their review of systematic literature on the African continent, conclude that a more sustained effort must be undertaken to develop research in logistics and SCM (Cf. table 1).

Table 1. Publications per research laboratory

\begin{tabular}{|l|c|c|}
\hline Nom de laboratoires & $\begin{array}{l}\text { Appartenance/ } \\
\text { laboratoires }\end{array}$ & $\begin{array}{l}\text { Publications/ } \\
\text { laboratoires }\end{array}$ \\
\hline EROP; LML ; LMIGEA; & & \\
ERETTIL; LCME; GRMSI; & & 1 \\
LARCEPEM ; LEREMOS; & 1 & \\
LMLM; CRETLOG; LARNED; & & 2 \\
LMPGI; LPEL; ERMSI; & & 2 \\
GRECO; RN\&E & 2 & 2 \\
\hline EREMOR & 1 & 2 \\
\hline CRMC & 1 & 3 \\
\hline LRSIAD & 1 & 4 \\
\hline LEGDD & 1 & 6 \\
\hline LEMNA & 4 & $\mathbf{3 7}$ \\
\hline GREFAM & 2 & \\
\hline ERETTLOG & $\mathbf{2 8}$ & \\
\hline Total & & \\
\hline
\end{tabular}


In the same vein, the analysis of the results of the selected articles allowed us to note that several sectors are analyzed by the authors on logistics and SCM in Morocco (figure 3).

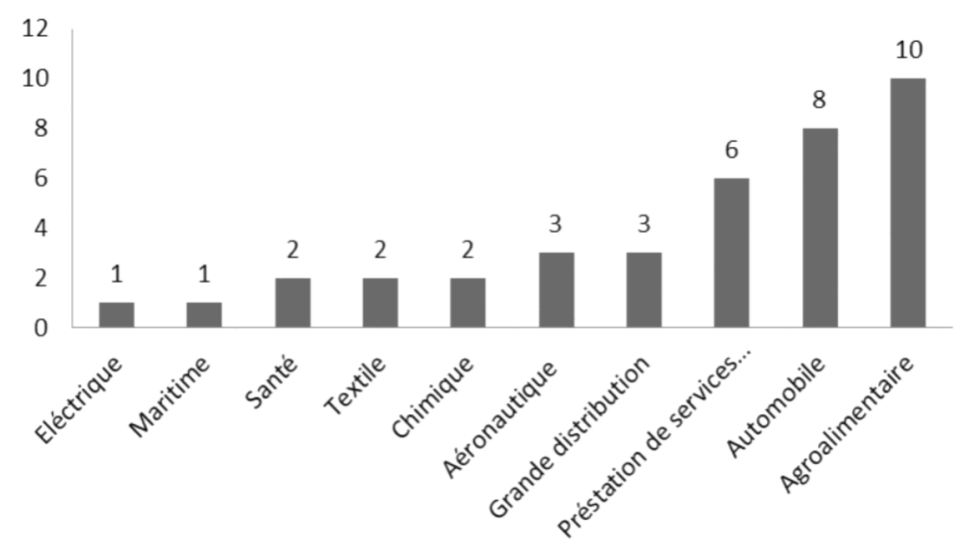

Figure 3. Distribution of articles by sector studied

The results show that the agri-food sector is the most studied in ten articles, followed by the automotive sector with eight articles published, six articles are linked to the provision of logistics service, three articles relate to large retailers, three articles on the aeronautics sector, two articles in the chemical, textile and health sectors and finally an article in the maritime sector and an article in the electrical energy sector. The results for the first two sectors seem consistent in the sense that the National Logistics Development Strategy relies on the agri-food flow and the import-export flow to develop the Moroccan competitiveness in logistics.

\subsection{Theoretical Approaches to Logistics and SCM}

The articles selected for this research were analyzed in relation to the theories used to study logistics and SCM in Morocco (Table 2). Thus, more than 36\% do not present any theoretical approach or model, especially when it comes to descriptive articles or literary journals. In a recent systematic review published by El Baz et al. (2018), the authors found that about $69 \%$ of the articles selected used theories to study logistics and SCM in the African context. In our systematic review in the Moroccan context, about $64 \%$ of the selected articles used theories and models in the context of research in logistics and SCM in Morocco. El Baz et al. (2018) have justified this theoretical underutilization in the context of research in Africa, among others, by the fact that research in logistics and SCM remains relatively recent and is currently being structured.

In our research, we will use the categorization proposed by El Baz et al. (2018). This categorization makes it possible to assign an article retained in our systematic review according to the theory or theories that are discussed. According to the results of our research, the following theories are used by the authors involved in research on logistics and SCM in Morocco from 2010 to 2018. More specifically, we have identified theories related to strategic management, marketing, microeconomics and macroeconomics, organizational behavior, sociology, mathematics, political science, decision science. Thus, $46 \%$ of the selected articles implemented theories related to microeconomics and macroeconomics (Nejjar, 2017; Abbad \& Bonet, 2011). About 1\% of the selected articles have used theories of sociology (Belhsen, 2016; Ouabouch \& Akrich, 2016; Benjelloun and Balambo, 2016; Aboudrar et al. 2014; Balambo, 2013; Mamad \& Ouazzani, 2013). Organizational behavior theories accounted for $15 \%$ of the theories used in the selected articles (Nejjar, 2017, Belhsen, 2016; Ouabouch and Akrich, 2016; Mamad and Ouazzani Chahdi, 2013, Moutimihi \& Achoui, 2016). 5\% of the selected articles used more strategic management theories (Elhasbi et al. 2017; Ameziane \& El Andaloussi, 2016) and theories of political science (Belhsen, 2016; Benbba \& Ameziane, 2010). Finally, only 3\% of the articles relied on the theories of Marketing (Aboudrar et al. 2014), decision sciences (Benrrezzouk, 2014) and mathematical models (Hajibi, 2011).

Among the selected articles, some research has combined different theoretical approaches to examine a specific topic of logistics or SCM in Morocco. For example, Aboudrar et al. (2014) studying how fruit and vegetable exporting companies in the Souss Massa Drâa region resort to the outsourcing of transport operations to improve their performance, these authors have used the theory of the agency, the theory of costs transaction, relationship 
marketing and network theory. On the other hand, Benrrezzouk (2014) by studying the importance of information systems technologies in the management of the supply chain in a perspective of strategic inter-organizational co-alignment has used the theory of transaction costs, the theory of games and the theory of the agency. In attempting to evaluate the relationship between business performance and the use of information technologies in the collaborative supply chain, Nejjar (2017) used transaction cost theory, contingency theory, and constraint theory. Benbba and Ameziane (2010) implemented different theories such as the theory of transaction costs, the theory of dependence of resources, the neo-institutional sociological current and the theory of justice to analyze the determinants of marketing and logistics in the collaboration between industrialists and distributors in the Moroccan retail sector. Still in this sense of theoretical combination, Ouabouch and Akrich (2016) in a literature review to attempt to examine how customer-supplier relations are apprehended in the literature in order to provide an analytical framework adapted to this type of inter-organizational relations in SCM. To do this, the authors relied on theories such as the theory of transaction costs, the theory of social exchange and the theory of resource dependence. Benbba and Ameziane (2010) relied on transaction cost theory and social exchange theory to define forms of opportunistic behavior as well as mechanisms for inter-organizational control of opportunistic behavior within SCs. Belhsen (2016) to test the effect of collaboration on logistics performance and organizational performance in thirteen agribusiness firms in the Casablanca and Tangier regions, using transaction cost theory, resource theory, institutional theory, resource dependency theory, and social exchange theory. In a case study, Abakouy and Housni (2016) used agency theory and transaction cost theory to describe and explain the logistical behavior of agribusiness SMEs in an international context. Elhasbi et al. (2017) in an effort to enhance the attractiveness of foreign investors in the manufacturing and logistics sectors in the city of Tangier implemented the strategic analysis PESTEL and the electrical theory developed by Dunning. Abbad et al. (2012) in an attempt to explain the nature of the barriers to ICT implementation in the food retail industry, have proposed theories such as transaction cost theory and the "innovation resistance" model. Finally, Mamad and Ouzzani Chahdi, (2013) relied on transaction cost theory and power and dependency theory to study the determinants of collaboration between SC actors in the automotive sector (Cf. table 2).

Table 2. Theories used in the selected articles

\begin{tabular}{lc}
\hline Theoretical approaches & Number of articles \\
\hline Microeconomics / Macroeconomics & 18 \\
sociology & 8 \\
Organizational behavior & 6 \\
strategic management & 2 \\
Political Sciences & 2 \\
Marketing & 1 \\
Decision Sciences & 1 \\
Mathematical & 1 \\
Total & 39 \\
\hline
\end{tabular}

In conclusion, the results of our systematic review clearly demonstrate that research work on logistics and SCM in Morocco implemented several theories from different disciplines. This reveals the diversity of research methods used by researchers to study logistics and SCM in the Moroccan context.

\subsection{Research Themes on Logistics and SCM in Morocco}

This systematic review of the literature on logistics and SCM in Morocco reveals that the articles have focused on various and relevant themes (Cf. figure 4). 


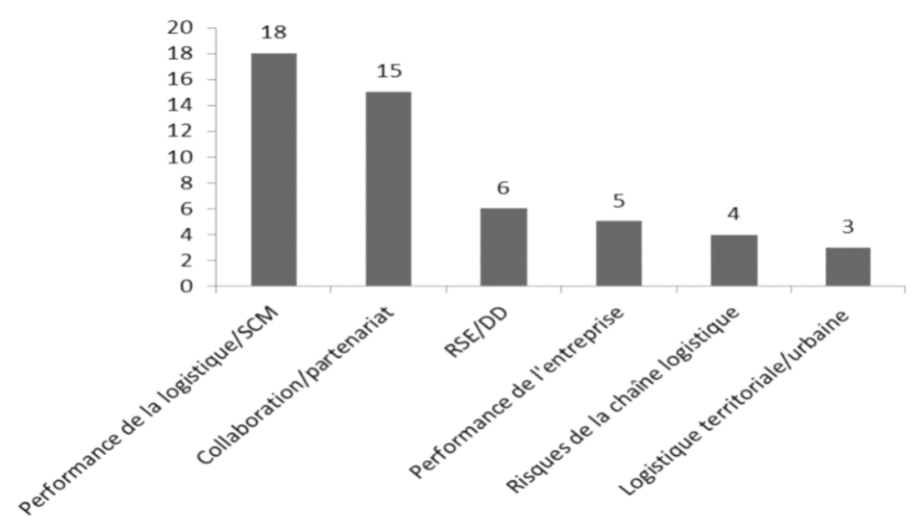

Figure. 4. Distribution of topics covered by selected articles

In this sense, about $35 \%$ of the selected articles studied the performance of the supply chain and /or SCM (Nejjar, 2017; Belhsen, 2016; Ouabouch and Akrich, 2016; Benrrezzouk, 2014; Aboudrar et al. 2014; Abbad et al. 2012; Moutimihi and Achoui, 2016; Hajibi, 2011; Ouabouch and Paché, 2014). Then, 27.5\% of the selected articles deal with collaborations and partnerships in the supply chain (Abakouy \& Housni, 2016; Alami \& Hdidou, 2016; Benbba \& Ameziane, 2010; Bahha et al. 2015; Benjelloun and Balambo, 2016; Mamad \& Ouazzani Chahdi, 2013; Balambo, 2013; Mamad \& Ouzzani Chahdi, 2013; Ameziane \& El Andaloussi, 2016; Jami, 2016; Abbad et al. 2013). The authors also studied topics related to CSR and sustainable development in the context of companies' logistical activities, but also the integration of sustainable development into the logistics activities of companies. In fact, about $14 \%$ of the selected articles deal with this topic in the Moroccan context (Ouriachi \& Taibouh, 2018; El Abdellaoui, 2018). In our systematic review, articles that dealt with supply chain risk (Ouabouch \& Akrich, 2016; Ouabouch \& Lavastre, 2015; Ouabouch \& Paché, 2014; Bouachouch \& Mamad, 2014; Ouabouch, 2016) account for about $10 \%$ of the items selected. In this sense, Ouabouch (2016) relied on a literature review on the risks related to the supply chain to propose the different types of risks, their sources, the strategies for their management and the means and methods used. For its part, Moh'd and Al-Shboul (2017) examined the impact of supply chain agility on business performance in the MENA region. Also, Bouachouch and Mamad (2014) in his study addressed the risks to the SCRM logistics chain in the automotive sector. For their part, Ouabouch and Akrich (2016) have instead studied the risks associated with CS in order to establish an analytical framework for inter-organizational relations within the SC. Always related to the risks of the supply chain, Ouabouch and Lavastre (2015) analyzed for a supply chain, the relationships between its vulnerability, its main risks and its performance.

Ouabouch and Paché (2014) evaluated the impact of risks in relation to the functioning of a supply chain and its performance. Finally, Moh'd and Al-Shboul (2017) studied inter-functional coordination within the supply chain and more specifically, the identification of antecedent inter-functional coordination in the context of a hospital supply chain. Finally, in this research articles selected studied the theme of urban logistics. These articles represent only 6\% of the total articles retained (Jami, 2018; Benbba and Ousslimane, 2017; Elhasbi et al. 2017). In his study, Jami (2018) raised several questions concerning the role that logistics could play in the development of the territory in particular, the public-private collaborations in this direction. Benbba and Ousslimane (2017) presented the state of urban logistics in global and that of Morocco in particular by specifying the organizational modes in particular, the urban logistic zones, the urban distribution centers, the points of reception of vehicles, the points of reception of goods and urban logistic boxes. Also, they specified the role of the PSL and the relevance and the impact of the different organizational modes on the latter and especially the organizational mode of the urban distribution centers. Finally, Elhasbi et al. (2017) using the PESTEL analysis, proposed the main factors of attractiveness of foreign investors in the manufacturing and logistics sector of the city of Tangier.

\section{Discussion and Conclusion}

The aim of this article is a mapping of academic research on logistics and supply chain management in Morocco to make a contribution to the literature on this field of research in this particular context. To attain this objective, we conduct a systematic review of articles published between 2010 and 2018. At the end of the selection process, fifty-one articles meet the inclusion criteria and are kept for further analysis.In the following, we will focus on 
the analysis of the main results emerging from this systematic review and we will suggest some recommendations and directions for practice and future research.

At first glance, we can underline the scarcity of research articles on logistics and SCM in the Moroccan context. In fact, despite both the breadth of the period covered by the study the keywords used to retrieve articles, only 289 articles were obtained. Although we have noticed an increasing path of publications over the period studied (2010-2018), with a significant increase in 2016, it remains low regarding the international scientific production on the field. For example, a recent systematic review conducted by El Baz et al (2018) on logistics and SCM in Africa, from 100 articles included in their study, we count only seven publications by Moroccan authors (Note 4). Accordingly, more has to be done in this area by encouraging research on this discipline through promoting international collaborative research as well as national collaboration. Regarding research at the national level, the results of our study revealed that some teams /laboratories are distinguished by the number of their publications. For example, ERETLOG team at Ibn Zohr University and GREFAM research group at Abdelmalek Essaâdi University in Tetouan are the most active teams in logistics and supply chain management research in Morocco. This lead could be explained by the proximity of these universities to major ports: Agadir and Tangier. Surprisingly, research laboratories from Casablanca universities are not as active as their colleagues in Ibn Zohr and Abdelmalek Essaâdi universities in logistics and SCM publication.

Second, our results suggest that publications included in our systematic review focused on two sectors nominally, food and automotive industries. Indeed, the growing interest in logistics and SCM research in the food industry could be related to the importance of this sector in the Moroccan economy. Actually, 27\% of the industrial production is related to this sector with $14 \%$ intended for export. Also, it is a sector with highly significant products' transformation (raw materials $\rightarrow$ finished products) and a large number of materials flows between manufacturers and supplier and between manufacturers and distributors as well. In addition to the food industry sector, the automotive sector has captured the interest of academic researchers in Morocco. Many reasons could explain this interest. In fact, this sector which is witnessing a remarkable growth is one of the seven world businesses of Morocco (MMM) called also in French "Métiers Mondiaux du Maroc", and one of the mainstays of the Emergence plan launched in 2005. Also, several global players have been implanted in Morocco, Renault-Nissan in Tanger in 2012 and Peugeot-Citroën in Kénitra in 2019. These implementations encourage the establishment of automotive suppliers in Morocco in order to support their headquarters. Alongside automotive suppliers, logistics service providers such as ID logistic and EasyDis, as well as professions that are concerned such wiring (Sews \& Yazaki), lighting (Valeo), and seats (Faurecia and Takata) have decided to establish their implantations in Morocco. As a result, several consulting firms such as ALTEN and ALTRAN set up their offices in Morocco. Accordingly, the industrial productivity in the Kingdom has made progress in terms of the evolution of its production exceeding 227,570 vehicles in 2014 against only 18,546 vehicles in 203 (Note 5), thus placing it in the global value chain of the automobile with 22 billion dirhams exported in 201 (Note 6). At the same time, this progress in terms of flows and multiplication and diversity of actors explain the growing interest of research in this sector as reflected by the large proportion of the articles included in our study.

Third, we were interested in exploring the theoretical foundations implemented mobilized by researchers to study logistics and SCM in Morocco. The results of our systematic review clearly demonstrate that several theories from different disciplines were used which reveals the diversity of the research methods used by researchers to investigate logistics and SCM problems in the Moroccan context. However, we noticed the lack of solid theoretical grounding for much of the work. In a majority of cases, articles, especially those retrieved from the IMIST database were a theoretical (Defee et al., 2010) which is relatively unfortunate for a research article. Thus suggesting that more attention should be given, by Moroccan researchers, to the theoretical foundation even if that logistics research and SCM is still relatively new and is in the process to be more structured (El Baz et al., 2018).

Finally, we were interested in studying the research themes in selected articles. $35 \%$ of them focused directly or indirectly on the performance of the supply chain, $27 \%$ of the selected articles deal with collaborations and partnerships in the supply chain, $14 \%$ on CSR and sustainable development and $8 \%$ on risk management in supply chain. The predominance of studies related to the "performance" of the supply chain can be explained by the general nature of this concept. In fact, firms seek to generate profits which allow them to pay their expenses and make investments. This reflects some aspects of this performance. Also, these results show the growing concern among Moroccan firms to find ways to enhance their logistics performance and among researchers to investigate factors that could enhance this performance.

The results of our systematic review highlight several pathways which require more attention from researchers to better channel their efforts in studying logistics and SCM in Morocco. We will summarize the main pathways in 
the following paragraphs. We should keep in mind that these recommendations are based on the results of our findings and thus they should be considered as suggestions since the main resources of our data are based on a national database which prevents us from accessing highly relevant studies.

First, we recommend to researchers to extend their networks of collaboration with firms operating in these two sectors (automotive and food industries) but also include others, such as aeronautics and large modernized distribution. In fact, aeronautics continues to develop in Morocco with the establishment of several world-class operators in the sector like the Canadian Bombardier. Large distribution (food and non-food) continues to grow with the arrival of foreign operators since 2009 such as Carrefour and BIM, the Turkish hard-discounter. We believe that the sectors cited above present promising fields for investigation by Moroccan researchers. In addition, the Moroccan context presents some particularities which deserve to be studied and thus shared between scientific and the professional communities.

Second, research on logistics and SCM is recent, at least in Africa (El Baz et al., 2018), this inherent characteristic of the discipline informs about the research journey that should be browsed to achieve a level of maturity in the field. As a consequence, we suggest to researchers to focus more on investigating themes related to actors' behaviors which are bounded to firms performance and ultimately to that of the supply chain. Indeed, using the behaviorist approach can foster our understanding of many stakeholder behaviors. In the context of the supply chain, we recommend that researchers should show more interest in investigating the determinants of cooperation and even competition among supply chain actors. In fact, increased competition between actors has forced firms to look for strategic and organizational alternatives outside their boundary span such as, creating new partnerships and building cooperation with competitors and so on. The study of these potentialities, offered by the diversity of supply chain partners, and their link to performance requires form researchers to rely more on innovative approaches, essentially behavioral approaches.

Third, some industries are showing a great deal of actors' integration such the one involving Findy, and Excelo in the food industry and Renault-Nissan with certain Original Equipment Manufacturers. These cases are not isolated and more actors' integration is to come in the near future as the dynamics of automobile growth are intensifying and success is increasing. Thus, we suggest that future research should focus on the study of the determinants of actors' integration in the supply chain.

Finally, the geographical position of Morocco and its proximity to Europe make of it a privileged place for offshoring. In the automotive industry, PSA and Renault-Nissan are an example of this phenomenon. Besides, the local sourcing policy and the organization of the upstream supply chain are themes that should attract Moroccan researchers' attention. While automotive and food industries seem to get more attention from policymakers than aeronautics and textile industries, researchers on the other side should shed light on these phenomena in the latter sectors.

Although this study offers interesting contributions to the literature and implications for researchers, we must also point out the main limitations of our study. Firstly, our study only includes articles published in peer review journals. In fact, we did not consider other types of research reports such as conference proceedings, books, newspapers articles, etc. which reduces the scope of the knowledge produced about logistics and SCM in Morocco. Secondly, the results of our systematic review remain descriptive which reduces the depth of the analysis about the strengths and weaknesses related to this literature. However, this study makes it possible to map and gather systematically the results of Moroccan researchers in logistics and supply chain management. We proposed an inventory of these results and orientations for future research while taking into account of the current business context in the Kingdom.

\section{References}

Abakouy, M., \& Housni, H. (2016). Export logistics between do and make do: case of a Moroccan SME in the food-processing sector. Revue Marocaine de Management, Logistique et Transport, (1). Retrieved from https://revues.imist.ma/index.php/RMLT/article/view/12170

Abbad, H., \& Fernandez, D. B. (2011). Résolution des conflits: le rôle des relations interpersonnelles dans les rapports grands distributeurs-PME marocaines. Maghreb-Machrek, (3), 27-42. https://doi.org/10.3917/machr.209.0027

Abbad, H., Paché, G., \& Bonet Fernandez, D. (2012). Peut-on désormais parler d'engagement du distributeur dans la relation avec l'industriel? Management international/International Management/Gestiòn Internacional, 16(4), 103-116. https://doi.org/10.7202/1013152ar

Abbad, H., Paché, G., \& Fernandez, D. B. (2013). Building a long term relationship between manufacturers and 
large retailers: does commitment matter in Morocco? Journal of Applied Business Research, 29(5), 1367-1380. https://doi.org/10.19030/jabr.v29i5.8020

Aboudrar, L., Elbaz, J., \& Batrich, H. (2014). Impact de l'externalisation du transport/logistique sur le triptyque coût-qualite-delai: cas des entreprises marocaines. Dossiers de Recherches en Économie et Gestion, 3(2), 463-484. Retrieved from https://revues.imist.ma/index.php/DOREG/article/view/15302

Acharki, H. H., Azdod, M. M., Bakhat, R. R., \& Rajaa, M. M. (2016). Pooling logistics and sustainable development: The paradox of" competitive advantage/coopetition" toward the sustainable thinking. Strategy Management Logistics, 1(1). Retrieved from https://revues.imist.ma/index.php/MLS/article/view/6808

AchouI, M., \& Moutmihi, M. (2016). La gestion et le renforcement des compétences dans l'entreprise étendue: Cas du secteur de transport routier de marchandises dangereuses. Revue d'Etudes en Management et Finance d'Organisation, 1(3). Retrieved from https://revues.imist.ma/index.php/REMFO/article/view/5557

Alami, Y., \& Hdidou, W. (2016). Contribution à la compréhension des relations d'externalisation logistique: le point de vue d'un PSL marocain. Revue Marocaine de Management, Logistique et Transport, (1). Retrieved from https://revues.imist.ma/index.php/RMLT/article/view/12161

Alderson, P., Green, S., \& Higgins, J. (2004). About The Handbook. Cochrane Reviewers' Handbook, 1.

Al-Shboul, M. D. A. (2017). Infrastructure framework and manufacturing supply chain agility: the role of delivery dependability and time to market. Supply Chain Management: An International Journal, 22(2), 172-185. https://doi.org/10.1108/SCM-09-2016-0335

Ameziane, H. (2016). L'impact des stratégies SCRM6 sur la résilience des chaines logistiques: un modèle conceptuel. Revue Marocaine de Management, Logistique et Transport, (1). Retrieved from https://revues.imist.ma/index.php/RMLT/article/view/12159

Bahha, N. (2016). La satisfaction de la relation fournisseur de marque de distributeur (MDD)-distributeur: explication par le prisme de la proximité (Doctoral dissertation, Aix-Marseille).

Bahha, N., Hdidou, W., \& EL Kartit, I. (2015). Outsourcing of logistics functions: a case study of a Moroccan retailer. International Journal of Finance, Business, Economics, Marketing and Information Systems, 1(1), 15-29. Retrieved from https://ase-scoop.org/journals/jBusinessAndEconomics/papersFBE/2.Bahha.pdf

Balambo, M. A. (2013). Culture nationale et nature de l'intégration des supply chains amont: le cas des équipementiers automobiles marocains. Logistique \& Management, 21(4), 71-85. https://doi.org/10.1080/12507970.2013.11517036

Belhsen, N. (2016). Collaboration interentreprises, performance logistique et performance organisationnelle: Cas des PME. Revue Marocaine de Management, Logistique et Transport, (1). Retrieved from https://revues.imist.ma/index.php/RMLT/article/view/12160

Benbba, B. (2016). Les Cluster Supply Chains: Une nouvelle piste pour améliorer l'agilité des chaînes logistiques. Revue Marocaine de Management, Logistique et Transport, (1). Retrieved from https://revues.imist.ma/index.php/RMLT/article/view/12157

Benbba, B., \& Ameziane, H. (2010). Analyse de la collaboration marketing et logistique entre industriels et distributeurs: le cas de la grande distribution marocaine. Revue Marocaine de Gestion et d'Economie, (2). https://revues.imist.ma/index.php/MLS/article/view/9696

Benbba, D., \& Ousslimane. (2017). Logistique urbaine au Maroc: état des lieux et voies d'améliorations. Strategy Management Logistics, 1(2). https://revues.imist.ma/index.php/MLS/article/view/9696

Benjelloun, K., \& Balambo, M. A. (2016). Comment un acteur fortement dépendant, peut subir l'exercice de la puissance commerciale: analyse sur la base de l'approche transactionnelle et de l'approche par le pouvoir et la dépendance. Strategy Management Logistics, 1(1). Retrieved from https://revues.imist.ma/index.php/MLS/article/view/6821

Benmabrek, H., \& Hamri, H. (2014). Engagement, partage d'information et collaboration fournisseurs-clients dans la chaîne logistique: Cas des PMI Marocaines. Revue Marocaine de Recherche en Management et Marketing, (9-10). Retrieved from https://revues.imist.ma/index.php/REMAREM/article/view/3528

Benrrezzouq, R. (2015). Co-alignement entre stratégie des TSI et l'organisation de l'échange dans la chaine logistique. Dossiers de Recherches en Économie et Gestion, 4(2), 91-114. Retrieved from https://revues.imist.ma/index.php/DOREG/article/view/15191 
Bouachouch, M., \& Mamad, M. (2014). Analysis of the antecedents of inter-functional coordination in the supply chain context: case of the medicament flows in a Moroccan university hospital. International Journal of Business and Management, 9(8), 97. https://dx.doi.org/10.5539/ijbm.v9n8p97

Colin, J. (2005). Le supply chain management existe-t-il réellement? Revue française de gestion, (3), 135-149. https://doi.org/10.3166/rfg.156.135-149

Daanoune, R., \& Lhassan, I. A. (2016). Capital humain et performance logistique Cas d'entreprises de la région du nord du Maroc. Dossiers de Recherches en Économie et Gestion, 5(2), 193-206.

EL Abdellaoui, M. (2018). Investigation-Analyse des facteurs et des événements de risques liés à la chaîne logistique: cas Secteur Automobile au Maroc. Revue des Etudes et Recherches en Logistique et Développement. https://dx.doi.org/10.2139/ssrn.3634921

El Baz, J., \& Laguir, I. (2017). Third-party logistics providers (TPLs) and environmental sustainability practices in developing countries. International Journal of Operations \& Production Management. https://doi.org/10.1108/IJOPM-07-2015-0405

El Baz, J., Frei, R., \& Laguir, I. (2018). Reverse supply chain practices in developing countries: the case of Morocco. Journal of Manufacturing Technology Management. https://doi.org/10.1108/JMTM-04-2017-0068

El Baz, J., Laguir, I., \& Stekelorum, R. (2019). Logistics and supply chain management research in Africa. The International Journal of Logistics Management. https://doi.org/10.1108/IJLM-09-2017-0242

EL Imrani, O., \& Babounia, A. (2016). Tangier Med Port: What role for the Moroccan Economy and the International Trade? International Journal of Research in Management, Economics and Commerce, (7), 73-81. Retrieved from http://www.indusedu.org/pdfs/IJRMEC/IJRMEC_896_93388.pdf

Elbaz, J., Laguir, I., \& Balambo, M. A. (2014). Quelle influence de la responsabilité sociale des entreprises (RSE) sur la sélection des prestataires de services logistiques (PSL)? Etude exploratoire des entreprises marocaines. Logistique \& Management, 22(1), 57-66. https://doi.org/10.1080/12507970.2014.11517044

Elhasbi, A., Barkaoui, M., Bouksour, O., \& Kamach, O. (2017). Les déterminants de l'attractivité territoriale des entreprises manufacturières et logistiques étrangères: application à la ville de Tanger-Maroc. La Revue Gestion et Organisation, 9(1), 25-36. https://doi.org/10.1016/j.rgo.2017.05.002

ELhasbi, A., Kammas, S., \& Jihad, J. A. M. I. (2016). Le Transport Durable au Maroc: Quels facteurs de contingence pour quel niveau de maturité? Revue des Etudes et Recherche en Logistique et Développement, 1, 1-19. https://revues.imist.ma/index.php/RERLED/article/view/8096

Elouidani, A., \& Amina, K. A. D. A. (2015). Déterminants de la Performance Portuaire: Cas du Port d'Agadir. Revue de Gestion et d'Économie, 3(2), 110-126. https://revues.imist.ma/index.php/jbe/article/view/3276

Ennesraoui, D. (2014). Logistique et satisfaction des exigences du client. Revue Marocaine de Recherche en $\begin{array}{cccc}\text { Management } & \text { et } & \text { Marketing, } & \text { Retrieved }\end{array}$ https://revues.imist.ma/index.php/REMAREM/article/view/3527

Fox, D. M. (2005). Evidence of evidence-based health policy: the politics of systematic reviews in coverage decisions. Health Affairs, 24(1), 114-122. https://doi.org/10.1377/hlthaff.24.1.114

Hajbi, A. (2011). Traffic forecasting in Moroccan ports. In Supply Chain Forum: An International Journal, 12(4), 26-35. https://doi.org/10.1080/16258312.2011.11517278

Hemsley-Brown, J., \& Sharp, C. (2003). The use of research to improve professional practice: A systematic review of the literature. Oxford Review of Education, 29(4), 449-471. https://doi.org/10.1080/0305498032000153025

Hou, M. A., Grazia, C., \& Malorgio, G. (2015). Food safety standards and international supply chain organization: A case study of the Moroccan fruit and vegetable exports. Food Control, 55, 190-199. https://doi.org/10.1016/j.foodcont.2015.02.023

Jami, J. (2016). Etude de la relation Qualité-Satisfaction-Fidélité en matière de service inter organisationnel. Revue des Etudes et Recherche en Logistique et Développement, 1, 95-117. Retrieved from https://revues.imist.ma/index.php/RERLED/article/view/8100

Jihad, J. A. M. I. (2018). Transport, logistique et territoire: Réflexions et propositions de solutions durables. Le cas du Maroc. Revue des Etudes et Recherche en Logistique et Développement, 1, 1-9. Retrieved from 
https://revues.imist.ma/index.php/RERLED/article/view/11758

Lemtaoui, M., Rochdi, M. H., \& Eloueldrhiri, S. (2017, April). Measuring the supply chain performance in Morocco: Application of the Edward Frazelle's model. In 2017 International Colloquium on Logistics and Supply Chain Management (LOGISTIQUA) (pp. 188-192). IEEE. https://doi.org10.1109/LOGISTIQUA.2017.7962896

Mamad, M., \& Chahdi, F. O. (2013). Collaboration within the Supply Chain: Perception for the Automotive Industry in Morocco. International Journal of Academic Research in Accounting, Finance and Management Sciences, 3(3), 211-220. http://doi.org/10.6007/IJARAFMS/v3-i3/131

Mamad, M., \& Chahdi, F. O. (2013). The factors of the collaboration between the upstream supply chain actors: case of the automotive sector in Morocco. International Business Research, 6(11), 15. http://dx.doi.org/10.5539/ibr.v6n11p15

Mhaezi, H. (2016). Supply chain durable au Maroc: état des lieux, motivations et obstacles. Strategy Management Logistics, 1(1). https://revues.imist.ma/index.php/MLS/article/view/6812

Moynihan, R. (2004). Evaluating health services: A reporter covers the science of research synthesis (pp. 1-55). New York, NY: Milbank Memorial Fund.

Nejjar, B. (2017). L'usage des technologies de l'information dans la logistique collaborative et son impact sur la performance des firmes. Information Systems Management and Innovation, 1(1), 23-38. Retrieved from https://revues.imist.ma/index.php/ISMI/issue/archive

Ouabouch, L. (2016). Etat de la recherche sur les concepts et les approches methodologiques de la gestion des risques lies a la supply chain. Revue Economie, Gestion et Société, (6). Retrieved from http://revues.imist.ma/?journal=REGS

Ouabouch, L., \& Akrich, S. (2016). Gouvernance des relations inter-organisationnelles en Supply Chain Management: dispositifs, management et performances. Revue Marocaine de Gestion et d'Economie, 3(7). Retrieved from http://revues.imist.ma/?journal=RMGE

Ouabouch, L., \& Lavastre, O. (2015). Vulnérabilité, risque et performance en Supply Chain Management Cas de l'industrie agroalimentaire au Maroc. Logistique \& Management, 23(1), 71-89. https://doi.org/10.1080/12507970.2015.11665673

Ouabouch, L., \& Paché, G. (2014). Risk management in the supply chain: characterization and empirical analysis. Journal of Applied Business Research (JABR), 30(2), 329-340. Retrieved from https://clutejournals.com/index.php/JABR

Ouariti, O. Z., \& Zeroual, P. L. (2017). L'impact Des Systèmes D'information Sur La Performance Des Chaines Logistiques: Une Revue De Littérature. European Scientific Journal, 13(4), 284-300. https://doi.org/10.19044/esj.2017.v13n4p284

Ouriachi, N. (2018). La logistique durable: Un nouveau levier de management. Revue du contrôle, de la comptabilité et de l'audit, 2(1). Retrieved from https://www.revuecc.com

Regragui, Y., \& Al Meriouh, Y. (2017). Etude exploratoire de l'impact des systèmes d'information sur la performance à partir d'une approche par alignement: cas des entreprises marocaines. European Scientific Journal, 13(31), 261-289. https://doi.org/10.19044/esj.2017.v13n31p261

Tranfield, D., Denyer, D., \& Smart, P. (2003). Towards a methodology for developing evidence-informed management knowledge by means of systematic review. British Journal of Management, 14(3), 207-222. https://doi.org/10.1111/1467-8551.00375

Zaugg, V., Savoldelli, V., Sabatier, B., \& Durieux, P. (2014). Améliorer les pratiques et l'organisation des soins: méthodologie des revues systématiques. Santé publique, 26(5), 655-667. https://doi.org/10.3917/spub.145.0655

\section{Notes}

Note 1. https://www.agility.com

Note 2. http://www.amdl.gov.ma

Note 3. http://www.mapexpress.ma 
Note 4. Mamad and Chahdi; Bouachouch and Mamad; Ouabouch and Paché; Abbad, Senkel, and Dari; Bahha, Hdidou, and El Kartit; Elbaz, Balambo, and Laguir; Hajbi

Note 5. https://www.finances.gov.ma

Note 6. https://lavieeco.com/news/economie/plan-emergencea-offshoringautomobile-et-aeronautique.html

\section{Copyrights}

Copyright for this article is retained by the author(s), with first publication rights granted to the journal.

This is an open-access article distributed under the terms and conditions of the Creative Commons Attribution license (http://creativecommons.org/licenses/by/4.0/). 